\title{
THE INFLUENCE OF EXPERIENTIAL MARKETING ON CUSTOMER LOYALTY THROUGH CUSTOMER SATISFACTION AS AN INTERVENING VARIABLE FOR MAHAKAM LANTERN GARDEN VISITORS
}

\author{
Lorine Kalista Noor ${ }^{1}$, Rahmawati ${ }^{2}$, Yohanes Kuleh ${ }^{3}$ \\ ${ }^{1,2,3}$ Master of Management Faculty of Economics and Business, University of Mulawarman \\ E-mail:_kk.noor@hotmail.com,Rahmawati@feb.unmul.ac.id, \\ Yohanes.kuleh@feb.unmul.ac.id
}

\begin{abstract}
This study aims to determine the effect of Experiential Marketing on Customer Loyalty (Study in Mahakam Lantern Garden Customers). The existence of tourism activities has a very big impact, one of which is reducing unemployment and increasing the standard of living of the surrounding community.The population in this study were visitors to Mahakam Lampion Garden, the sample in this study were 100 visitors. Methods of data collection are carried out by distributing questionnaires or questionnaires to respondents who become the research sample. This study used data analysis tools, namely the validity and reliability tests, so this study used the partial least square (PLS) analysis method. The tools used in data processing using the PLS Smart program. The results showed that 1) Experiential marketing had a significant effect on Mahakan Lantern Garden customer loyalty, 2) Experiential Marketing and Customer Satisfaction had a significant effect on Mahakan Lantern Garden Customer Loyalty,
\end{abstract}

Keywords: $\quad$ Experiential Marketing, Customer Loyalty, Customer Satisfaction.

\section{Introduction}

The tourism industry in Indonesia is growing rapidly in line with the advancing world economic growth and the easy access to available information. Kota Samarinda is one of the cities where the tourism sector is developing. According to (Morrison, 2000) There are three parts in the hospitality industry, including lodging operations, food and beverage service, and travel / tourism. The industry is an industry that provides services to the community, one of which is by providing tourism accommodation. In addition to the accommodation business, in the hospitality industry there is a food and beverage service, which includes food services, namely restaurants.

According to(Dick \& Basu, 1994)stated customer loyalty is the strength of the relationship between a person's relative attitude and repeat business. Meanwhile, what is meant by a loyal customer is someone who repurchases from the same company, notifies other potential customers by word of mouth and becomes an antidote to attacks from his competitors.(Evans, JK and Laskin, 2004).

Experiential marketing is the ability of a product to offer emotional experiences that touch the hearts and feelings of consumers. In the experiential marketing strategy consumers not only demand quality goods, but also want emotional benefits in the form of a memorable experience, namely an unforgettable memorable experience, a unique positive experience and also a holistic experience through all of their 
five senses. There are two focus frames of work from experiential marketing, namely: Strategic Experiential Moduls (SEMs) and Experiential Providers (ExPros).

Strategic Experiential Moduls (SEMs) is to provide experiences to consumers through five types of experience, namely, through sense, feel, think, act and relate. Meanwhile, Experiential Providers (ExPros) is an experiential marketing tactical tool. The media used are: Communication, Visual / verbal identities, Products, Co-branding, Environment, Electronic Media / Website, People.

Based on research from(Amrullah, 2018) which is related to experiential marketing which has the title "The Influence of Experiential Marketing on Consumer Loyalty with Satisfaction as an Intervening Variable" states that consumer satisfaction mediates the effect of experiential marketing on consumer loyalty in Malang Culinary Sengkaling.

However, research from(Arsjad, 2019) with the same title, namely "The Influence of Experiential Marketing on Consumer Loyalty with Satisfaction as an Intervening Variable" with the location at McDonald Watu Gong Malang has different research results that state that satisfaction cannot mediate the relationship between experiential marketing and consumer loyalty.

From the research above, it is found that there is a gap between the results of one study with another, namely the role of the consumer satisfaction variable as a mediating variable with positive and negative effects. Therefore, further research on these variables needs to be done.

(Kertajaya, 2003)states that if the company can create experiences for consumers, consumers will remember forever then will make repeat purchases based on that experience. This strategy is considered very influential as evidenced by the research conducted(Rini, 2009)said that when using experiential marketing strategies, it will affect consumer loyalty, the more experiential marketing that is presented, the more loyalty will increase. Several researchers and academics have conducted previous research on experiential marketing in various cities, but they have different findings with the theory and factors that influence consumer loyalty. Therefore, these factors deserve to be tested again, especially on Mahakam Lantern Garden visitors.

Given the descriptions and contradictions of several previous studies, the researcher wants to develop it so that it can be reviewed with the location at Mahakam Lampion Garden.

The formulation of the problem in this study is as follows:

1. Does experiential marketing directly affect the loyalty of visitors to the Mahakam Lantern Garden?

2. Does experiential marketing indirectly influence the loyalty of Mahakam Lantern Garden visitors?

3. Does visitor satisfaction mediate experiential marketing towards loyalty at Mahakam Lampion Garden?

\section{Research methods}

This research has a quantitative approach, descriptive and associative types. It is said that it is a quantitative approach because the approach used in the research proposal, analysis and conclusion of the data up to writing uses aspects of measurement, calculation, formula and certainty of numerical data. This research is a descriptive study because it aims to create a hostage / painting / descriptive study of the facts and characteristics of a particular population or area in a systematic, factual and thorough manner.(Understanding Ginting Syafrizal Helmi Situmorang, 2013). While it is said to be associative research because this research connects two or more variables.

Population is the entire collection of elements that have certain characteristics in common and have the same opportunity to be selected as sample members(Umar, 2011). The population in this study were 570 visitors to the Mahakam Lampion Garden. In this study the authors narrowed the population, namely the total number of visitors as many as 570 visitors. 
International Journal of Economics, Business and Accounting Research (IJEBAR)

Peer Reviewed - International Journal

Vol-4, Issue-3, 2020 (IJEBAR)

E-ISSN: 2614-1280 P-ISSN 2622-4771

https://jurnal.stie-aas.ac.id/index.php/IJEBAR

Because this study uses a sample. Sample is a part of all individuals who become the object of research. In order for the number of samples used to be representative of the population, the number of samples used is 100 visitors to Mahakam lampion Garden.

\section{Results and Discussion}

\subsection{Result}

Based on the answers given by the respondents in this study, some of the criteria for the recipient can be explained, namely the identity of the respondent which includes gender, age, latest education and occupation.

Table 3.1

Based on Gender

\begin{tabular}{|c|c|c|c|}
\hline No. & Gender & Frequency & Percentage \\
\hline 1 & Men & 32 & $32 \%$ \\
\hline 2 & Woman & 68 & $68 \%$ \\
\hline \multicolumn{2}{|c|}{ Total } & 100 & $100 \%$ \\
\hline
\end{tabular}

Source: Data processed, 2020

In table 3.1 above, it can be seen that out of 100 respondents, the number of respondents who were dominated by women was 68 respondents.

Table 3.2

Based on Age

\begin{tabular}{|c|c|c|}
\hline Age & Frequency & Percentage \\
\hline $18-25$ years & 70 & $70 \%$ \\
\hline $26-35$ years & 15 & $15 \%$ \\
\hline$>35$ years & 15 & $15 \%$ \\
\hline total & 100 & $100 \%$ \\
\hline
\end{tabular}

Source: Data processed, 2020

In table 3.2 above, it can be seen that of the 100 respondents, the dominant number of respondents was respondents aged 18 to 25 years, as many as 70 respondents.

Table 3.3

Based on Gender

\begin{tabular}{|c|c|c|c|}
\hline \multicolumn{2}{|c|}{ Characteristics } & total & Percentage \\
\hline \multirow{4}{*}{ Education } & SD & 0 & 0 \\
\cline { 2 - 4 } & Junior High & 0 & 0 \\
\cline { 2 - 4 } & High school & 60 & $60 \%$ \\
\cline { 2 - 4 } & S1 & 38 & $38 \%$ \\
\cline { 2 - 4 } & S2 & 2 & $2 \%$ \\
\cline { 2 - 4 } & S3 & & \\
\hline \multicolumn{2}{|c|}{ total } & 100 & $100 \%$ \\
\hline
\end{tabular}

Source: Data processed, 2020

In table 3.3 above, it can be seen that of the 100 respondents, the number of respondents was the dominant respondent with high school education as many as 60 respondents. 
International Journal of Economics, Business and Accounting Research (IJEBAR)

Peer Reviewed - International Journal

Vol-4, Issue-3, 2020 (IJEBAR)

E-ISSN: 2614-1280 P-ISSN 2622-4771

https://jurnal.stie-aas.ac.id/index.php/IJEBAR

Table 3.4

Based on Job Status

\begin{tabular}{|c|c|c|}
\hline Profession & Frequency & Percentage \\
\hline Government employees & 20 & $20 \%$ \\
\hline entrepreneur & 13 & $13 \%$ \\
\hline College student & 53 & $53 \%$ \\
\hline Others & 14 & $14 \%$ \\
\hline total & 100 & $100 \%$ \\
\hline
\end{tabular}

Source: Data processed, 2020

In table 3.4 above, it can be seen that of the 100 respondents, the number of respondents was the dominant respondent with a job as a student as many as 53 respondents.

\subsection{Discussion}

Validity and reliability are used to test instruments in the form of indicators and questions to meet the requirements or can be used as measurement variables. Following are the results of testing the validity and reliability of the test instrument using PLS with a sample of 100 respondents:

Table 3.5

Validity and Reliability Test Results

\begin{tabular}{|c|c|c|c|c|c|}
\hline Variable & ITEM & Correlation & Result & $\begin{array}{c}\text { Cronbach's } \\
\text { Alpha }\end{array}$ & Result \\
\hline \multirow{7}{*}{$\begin{array}{l}\text { Experiential } \\
\text { Marketing }\end{array}$} & $\mathrm{X} 1.1$ & 0.796 & Valid $(>0.277)$ & 0.745 & $\begin{array}{l}\text { Reliable (> } \\
0.6)\end{array}$ \\
\hline & $\mathrm{X} 1.4$ & 0.815 & Valid $(>0.277)$ & 0.923 & $\begin{array}{l}\text { Reliable (> } \\
0.6)\end{array}$ \\
\hline & $\mathrm{X} 2.2$ & 0.686 & Valid $(>0.277)$ & 0.724 & $\begin{array}{l}\text { Reliable (> } \\
0.6)\end{array}$ \\
\hline & X3.1 & 0720 & Valid $(>0.277)$ & 0.749 & $\begin{array}{l}\text { Reliable (> } \\
0.6)\end{array}$ \\
\hline & X3.3 & 0.556 & Valid $(>0.277)$ & 0891 & $\begin{array}{l}\text { Reliable (> } \\
0.6 \text { ) }\end{array}$ \\
\hline & $\mathrm{X} 4.1$ & 0.558 & Valid $(>0.277)$ & 0.795 & $\begin{array}{l}\text { Reliable (> } \\
0.6 \text { ) }\end{array}$ \\
\hline & $\mathrm{X} 4.2$ & 0720 & Valid $(>0.277)$ & 0851 & $\begin{array}{l}\text { Reliable (> } \\
0.6)\end{array}$ \\
\hline Satisfaction & Z1.1 & 0833 & Valid $(>0.277)$ & 0.593 & Reliable (> \\
\hline
\end{tabular}


International Journal of Economics, Business and Accounting Research (IJEBAR)

Peer Reviewed - International Journal

Vol-4, Issue-3, 2020 (IJEBAR)

E-ISSN: 2614-1280 P-ISSN 2622-4771

https://jurnal.stie-aas.ac.id/index.php/IJEBAR

\begin{tabular}{|c|c|c|c|c|l|} 
& & & & $0.6)$ \\
\cline { 2 - 6 } & Z2.1 & 0.879 & Valid $(>0.277)$ & 0.806 & $\begin{array}{l}\text { Reliable }(> \\
0.6)\end{array}$ \\
\hline \multirow{5}{*}{ Loyalty } & Y2.1 & 0.647 & Valid $(>0.277)$ & 0.917 & $\begin{array}{l}\text { Reliable }(> \\
0.6)\end{array}$ \\
\cline { 2 - 6 } & Y2.2 & 0840 & Valid $(>0.277)$ & 0831 & $\begin{array}{l}\text { Reliable }(> \\
0.6)\end{array}$ \\
\cline { 2 - 6 } & Y3.1 & 0846 & Valid $(>0.277)$ & 0.712 & $\begin{array}{l}\text { Reliable }(> \\
0.6)\end{array}$ \\
\cline { 2 - 7 } & Y3.2 & 0.739 & Valid $(>0.277)$ & 0.787 & $\begin{array}{l}\text { Reliable }(> \\
0.6)\end{array}$ \\
\hline
\end{tabular}

Based on Table 3.5 above shows that the results of the validity test for a sample of 100 respondents, the reliability test was carried out by means of one shot, that is, if the value of the Cronbach's alpha variable $>0.60$ then the indicators used by these variables are reliable, while the Cronbach's alpha value of a variable $<0$, The 60 indicators used are unreliable variables. Based on the calculation results, the Cronbach's alpha value for each item has met the reliability requirements, the Cronbach's alpha value for each item has exceeded the minimum reliability level or Cronbach's alpha $>0.60$. This shows that in terms of questions all are reliable or will produce the same value, if there are two or more times.

\section{Goodness of Fit Model Exam}

Knowing the goodness-fit model can be seen from the R-Square value. The R-square value can be used to explain the effect of the independent variable on the dependent variable which has a substantive effect.

Table 3.6

Result of Structural Model Evaluation with R square

\begin{tabular}{|l|l|}
\hline Variable & R Square \\
\hline Consumer Loyalty & $\mathbf{0 . 7 0 5}$ \\
\hline Consumer Satisfaction & $\mathbf{0 . 2 1 9}$ \\
\hline
\end{tabular}

Source: SmartPLS output

Based on this table, it can be seen that the R-square for the customer loyalty variable is 0.705 and the customer satisfaction variable is 0.2019 . Goodness of Fit model is measured by using Q square (Q2). The value of Q2>0 indicates that the model has Predective Relevance. The magnitude of the value of Q2 has a vulnerable value of $0<\mathrm{Q} 2<1$. Each $\mathrm{R}$ value is as follows:

$$
\begin{aligned}
& \mathrm{Q} 2=1(1-\mathrm{R} 12) \\
& \mathrm{Q} 2=1(1-0.705)(1-0.219) \\
& \mathrm{Q} 2=0.769
\end{aligned}
$$

The Q2 value is 0.7769 or $76.9 \%$, the contribution of data that can be explained by the model is $76.9 \%$. While the remaining $23.1 \%$ is explained by other variables that have not been contained in this study. 
International Journal of Economics, Business and Accounting Research (IJEBAR)

Peer Reviewed - International Journal

Vol-4, Issue-3, 2020 (IJEBAR)

E-ISSN: 2614-1280 P-ISSN 2622-4771

https://jurnal.stie-aas.ac.id/index.php/IJEBAR

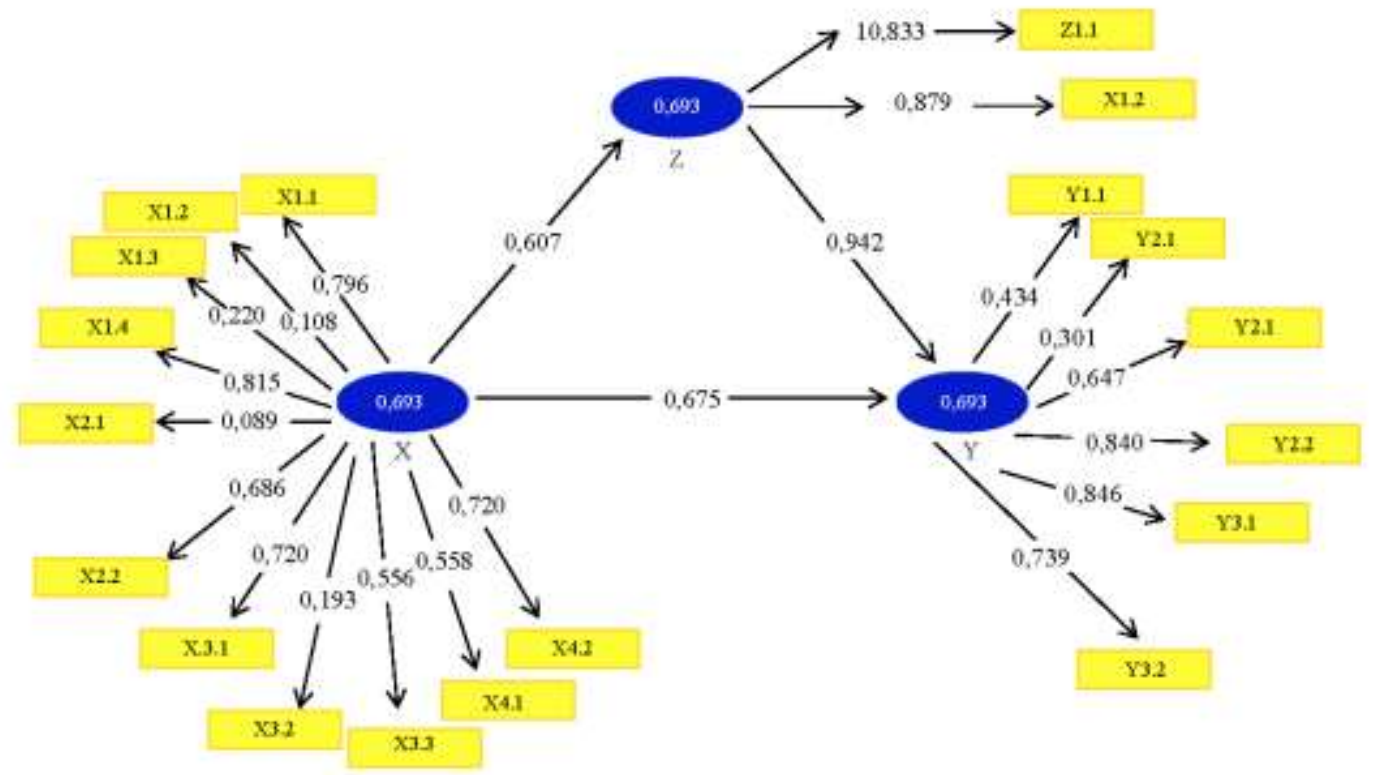

Figure 3.1

The SmartPLS program is carried out by t-test on each path with a direct effect (bootstrapping) and an indirect effect. The results of the direct effect test can be seen in table 5.21 below.

Table 3.7

Bootstrapping Test

\begin{tabular}{|l|l|l|l|l|l|}
\hline & $\begin{array}{l}\text { Original } \\
\text { Sample } \\
\text { Estimate }\end{array}$ & $\begin{array}{l}\text { Sample } \\
\text { Mean (M) }\end{array}$ & $\begin{array}{l}\text { Standard } \\
\text { Deviation }\end{array}$ & $\begin{array}{l}\text { T } \\
\text { Statistics }\end{array}$ & P Value \\
\hline $\begin{array}{l}\text { Experiential } \\
\text { Marketing -> } \\
\text { Consumer } \\
\text { Loyalty }\end{array}$ & 0.256 & 0.259 & 0.070 & 3,675 & 0.000 \\
\hline $\begin{array}{l}\text { Experiential } \\
\text { Marketing -> } \\
\text { Satisfaction }\end{array}$ & 0.468 & 0.472 & 0.084 & 5,607 & 0.000 \\
\hline $\begin{array}{l}\text { Satisfaction -> } \\
\text { Consumer } \\
\text { Loyalty }\end{array}$ & 0.689 & 0.687 & 0.063 & 10,942 & 0.000 \\
\hline
\end{tabular}

Source: SmartPLS output

With the hypotheses formulated in the previous chapter, the results of hypothesis testing in table 3.7 can be summarized as follows:

- The first hypothesis (H1) = states that Experiential Marching has a significant positive effect on direct consumer loyalty. The test results show that the experiential marketing variable measured by sense, feel, link and act has a T-statistic value of 3,675 and a p-value of 0,000, while the critical (t-table) is 1,969 and a p-value of less than 0.05 or $5 \%$. The results of this test indicate that the T-statistic value $>$ critical value ( $t$-table) and $\mathrm{p}$-value $<0.05$. This shows that the experiential marketing variable has a direct and significant effect on consumer loyalty, or in other words $\mathrm{H} 1$ is accepted. That is,

- $\quad$ The second hypothesis $(\mathrm{H} 2)=$ Hypoesis states that experiential marketing has a significant 
positive effect on consumer loyalty indirectly through the customer satisfaction variable. The test results show that the experiential marketing variable measured by sense, feel, think and act has a T-statistic value of 6.545 and a p-value of 0.000 , while the critical value (t-table) is 1.969 and a pvalue is less than 0.05 or $5 \%$. The test results show that the $\mathrm{T}$-statistic value $>$ crisis value (t-table) and $\mathrm{p}$-value $<0.05$. This shows that the experiential marketing variable has an indirect and significant effect on consumer loyalty, or in other words, $\mathrm{H} 2$ is accepted.

- $\quad$ The third hypothesis $(\mathrm{H} 3)=$ The third hypothesis states that customer satisfaction mediates experiential marketing towards customer loyalty. Testing the mediation variables using the Sobel Test. The Sobel Test is used to test the strength of the indirect effect between the Experiential Marketing (X) variable on Consumer Loyalty (Y) through the Consumer Satisfaction (Z) variable.

\section{Conclusion}

Regarding the relationship between variables in the model, based on the results of the analysis that have been stated in the previous chapter, the following conclusions can be drawn:

1. Experiential marketing variables can directly and positively affect visitor loyalty significantly and positively on the Mahakam Lantern Garden. Evidenced by the test results using PLS 3. This means that the more companies create experiential marketing or unique and unforgettable experiences for visitors, the more loyalty visitors will give to the Mahakam Lantern Garden.

2. Experiential marketing variable can indirectly influence consumer loyalty through the consumer decision variable significantly in the Mahakam Lantern Garden. Based on the sobel test, customer satisfaction is able to mediate the relationship between experiential marketing and consumer loyalty of Mahakam Lampion Garden.

\section{Suggestion}

Based on the conclusion of the research results, several suggestions can be found as follows:

1. For Mahakam Lantern Garden

From the results of this study, it can be concluded that the Mahalam Lampion Garden should continue to maintain affordable visitors in order to maintain their loyalty. Some suggestions for maintaining loyalty are:

a. This research should be taken into consideration in decision making by the leadership of Mahakam Lampion Garden in the marketing sector.

b. Be more creative in creating unique experiences and are created by the company when visitors visit so that it can create a feeling of surprise every time visitors come so that there is no feeling of boredom and an interest in visiting again.

c. Further improve the relationship with consumers through the intensity of the events that might be organized.

2. For Further Researchers

Those who will conduct further research are advised to:

a. Read and understand so as to add insight into knowledge about experiential marketing, customer satisfaction and customer loyalty.

b. Developing this research with different objects and adding other variables that can create consumer loyalty.

c. Increase the number of samples to get better research results

\section{References}

Amrullah, W. (2018). Pengaruh Experiential Marketing Terhadap Loyalitas Pelanggan Melalui Kepuasan Pelanggan Sebagai Variabel Intervening Di Sengkaling Kuliner "Sekul” Malang. Manajemen Bisnis, 
International Journal of Economics, Business and Accounting Research (IJEBAR)

Peer Reviewed - International Journal

Vol-4, Issue-3, 2020 (IJEBAR)

E-ISSN: 2614-1280 P-ISSN 2622-4771

https://jurnal.stie-aas.ac.id/index.php/IJEBAR

7(2), 119-128. https://doi.org/10.22219/jmb.v7i2.7006

Arsjad, M. P. (2019). Pengaruh Experiential Marketing, Kualitas Pelayanan dan Driver Attitude Terhadap Kepuasan Pelanggan (Studi kasus pada pengguna Grab di Kota Bogor). https://doi.org/10.31227/osf.io/tcdmh

Dick, A. S., \& Basu, K. (1994). Customer loyalty: Toward an integrated conceptual framework. Journal of the Academy of Marketing Science, 22(2), 99-113. https://doi.org/10.1177/0092070394222001

Evans, J.K. and Laskin, N. (2004). Searching for a definition of relationship marketing", Proceedings of the 3rd International Colloquium on Relationship Marketing. University of Melbourne, Australia, Monash University.

Kertajaya, H. (2003). Empathy Has Significant Contribution In Service Studi Kasus pada Spa Martha Tilaar. Jurnal Martha Tilaar Group, Hal, 27-28.

Paham Ginting Syafrizal Helmi Situmorang. (2013). Filsafat Ilmu dan Metode Riset. In Journal of Chemical Information and Modeling. https://doi.org/10.1017/CBO9781107415324.004

Rini, E. S. (2009). Menciptakan Pengalaman Konsumen . 2, 15-20.

Umar, H. (2011). Metode Penelitian untuk Skripsi dan Tesis Bisnis (Edisi 2). rajawali pers. 